\title{
PARTISIPASI POLITIK SANTRI PADA PEMILIHAN BUPATI ACEH BARAT 2017
}

\author{
Sudarman Alwy ${ }^{1)}$ Reza Febriandi ${ }^{2)}$ \\ ${ }^{1}$ Fakultas Ilmu Sosial dan Ilmu Politik Universitas Teuku Umar \\ Email.darman76alwy@gmail.com \\ ${ }^{2}$ Fakultas Ilmu Sosial dan Ilmu Politik Universitas Teuku Umar
}

\begin{abstract}
This research concerns to existence of Santri in dayah which are had the aim purpose to learning and deepen religious, so then very far away about the political information related then active involvement. Nevertheless, the opportunity to funneling their rights as good citizens for participate in the election uncertainly blocked, especially many of santri are beginner voters. More specifically, aim of this study to know about santri political participation in Pemilukada in Aceh Barat Regency 2017. This research uses qualitative method by involving 20 informants selected by using purposive sampling technique. The results indicated that the santri political participation is passive participatory then they had have never been directly involved in the successing of the campaign, they use only their political right to vote when voting process in TPS at the day. This participation is referred as the conventional participation form and lowest level participation hierarchy above the total apathy bit.
\end{abstract}

Keywords: Participation, Political, Santri, Dayah. 


\section{PENDAHULUAN}

Keberadaan masyarakat untuk berpartisipasi dalam politik merupakan salah satu bentuk aktualisasi dari proses demokrasi. Sebab partisipasi politik merupakan kegiatan seseorang atau kelompok masyarakat untuk ikut serta secara aktif dalam kehidupan politik, memilih pimpinan negara, dan juga berperan aktif secara langsung atau tidak langsung untuk mempengaruhi suatu kebijakan pemerintah (public policy). Dengan kata lain, peran warga negara untuk berpartisipasi dalam politik erat kaitannya dengan kesadaran politik, karena semakin sadar bahwa dirinya diperintah, orang tersebut kemudian menuntut diberikan hak bersuara dalam penyelenggaraan pemerintahan (Budiarjo, 2007, h.367).

Peran pesantren/dayah di masa lalu kelihatan paling menonjol dalam hal menggerakkan, memimpin, dan melakukan perjuangan dalam rangka mengusir penjajah (Arifin, 2007, h.231) Peran pesantren/dayah di masa sekarang juga amat jelas. Contoh yang paling nyata adalah sulitnya pemerintah memasyarakatkan program bila tidak melalui pemimpin dayah. Contoh lainnya adalah banyaknya pemimpin politik mendekati dayah, terutama menjelang pemilihan umum. Perilaku para pemimpin itu tepat, bila mereka tidak mendekati para pemimpin dayah, berarti visi politik mereka rendah (Tafsir, 2012, h.290).

Pesantren/dayah merupakan sebuah komunitas kecil masyarakat yang hidup dengan berlandaskan nilai-nilai ajaran agama Islam. Pesantren memiliki peraturan yang mengikat para santri. Peraturan tersebut dibuat dengan tujuan untuk mendidik para santri agar disiplin dan mandiri. Sehingga setelah menempuh pendidikan di pesantren, santri mampu beradaptasi dengan kehidupan masyarakat. Peranan pesantren/dayah dalam menggalang suara pemilu, menjadikan pesantren sebagai incaran partai politik. Namun, tidak semua pesantren ikut terlibat dalam politik praktis, hal ini tergantung pada pola kepemimpinan pesantren (Shofiya dan Yani, 2014, h.661).

Di Kabupaten Aceh Barat terdapat 86 pesantren/dayah yang tersebar di 12 kecamatan yaitu Johan Pahlawan (9), Samatiga (6), Bubon (6), Arongan Lambalek (10) Woyla (13), Woyla Barat (3), Woyla Timur (4), Kaway XVI (15), Meureubo (11), Pante Ceureumen (3), Panton Reu (2) dan Sungai Mas (4). Adapun jumlah keseluruhan santri yang belajar di 86 pesantren/dayah yang tersebar di seluruh Kabupaten Aceh Barat berjumlah 8.073 santriwan/santriwati dengan jumlah pengajar (Teungku) sebanyak 784 orang (Bappeda, 2014).

Santri yang dikategorikan sebagai pemilih pemula yaitu santri yang baru pertama kali mengikuti kegiatan pemilihan umum sebagaimana yang dikemukakan oleh Pahmi (2010, h. 54) bahwa pemilih pemula merupakan pemilih yang baru pertama kali memilih karena usia mereka baru memasuki usia pemilih yaitu 17 hingga 21 tahun. Pengetahuan mereka terhadap pemilu tidak berbeda jauh dengan kelompok lainnya, yang membedakan adalah soal antusiasme dan preferensi.

Dengan demikian, referensi pengalaman politik yang dimiliki masih rendah. Tingkat pengalaman politik santri sebagai pemilih pemula ini masih rendah apabila dibandingkan dengan pemilih secara umum, sehingga seringkali menimbulkan apatisme atau acuh tak acuh terhadap proses politik. Oleh karena itu dibutuhkan adanya orientasi politik dalam diri santri. Orientasi politik ini bertujuan untuk mengarahkan partisipasi politik santri, karena sebagai pemilih pemula tentu pengalaman yang dimiliki terkait proses atau kegiatan politik masih rendah.

Partisipasi politik lebih lanjut menurut Huntington dan Nelson (1994, h.12) dapat terwujud dalam berbagai bentuk studi tentang partisipasi dapat menggunakan skema-skema klarifikasi yang berbeda-beda yaitu:

1. Kegiatan pemilihan dengan mencakup suara akan tetapi juga sumbangan untuk kampanye, bekerja dalam suatu pemilihan, dengan mencari dukungan bagi seorang calon atau setiap tindakan yang bertujuan mempengaruhi hasil proses pemilihan. 
2. Lobbying merupakan dengan mencakup upaya perorangan atau kelompok untuk menghubungi pejabat-pejabat pemerintah dan pemimpin politik dengan maksud untuk mempengaruhi keputusan tentang persoalan yang telah menyangkut sejumlah besar.

3. Kegiatan organisasi dengan merupakan menyangkut partisipasi sebagai anggota atau pejabat dalam suatu organisasi yang tujuannnya yang utama dan eksplisit adalah dengan mempengaruhi pengambilan keputusan pemerintah orang.

4. Mencari koneksi dengan merupakan tindakan perorangan yang akan ditujukan terhadap pejabat pemerintah dan dengan memperoleh manfaat bagi hanya satu orang atau segelintir orang.

5. Tindakan kekerasan merupakan salah satu bentuk dari partisipasi politik dan untuk keperluan analisis ada manfaatnya untuk mendefinisikannya sebagai bentuk kategori tersendiri dengan sebagai upaya untuk mempengaruhi pengambilan keputusan dari pemerintah dengan jalan menimbulkan kerugian fisik terhadap orang ataupun harta benda.

Rendahnya partisipasi politik santri secara aktif dalam memilih Kepala Daerah dikarenakan santri kurang mendapatkan informasi mengenai latar belakang visi dan misi calon kepala daerah, karena keterbatasan akses santri untuk mendapatkan infromasi lengkap tentang calon Kepala Daerah, maka santri pun kurang mau terlibat dalam mensosialisasikan calon kepala daerah kepada santri lain atau masyarakat sekitar. Faktor lain yang menyebabkan partisipasi politik santri masih rendah, karena ruang gerak santri terbatas di tempat pemondokan, sehingga santri jarang keluar untuk ikut serta dalam kampanye-kampanye. Hal tersebut juga ada kaitannya dengan peraturan dayah yang tidak memperbolehkan santri ikut kampanye di luar, terkecuali apabila ada calon yang terlebih dahulu disosialisasikan oleh pimpinan pesantren untuk dipilih oleh santri.

Partisipasi santri sebagai pemilih pemula dalam pemilihan calon kepala daerah (Bupati dan Wakil Bupati) di Kabupaten Aceh Barat sangat penting untuk dapat menggunakan hak pilih yang dimiliki untuk memilih calon kepala daerah yang memiliki berkualitas dan memiliki kompetensi untuk memimpin. Huntington dan Nelson (1994, h.4) mengatakan bahwa partisipasi politik adalah kegiatan warga Negara yang bertindak sebagai pribadi-pribadi yang dimaksud untuk mempengaruhi pembuatan keputusan oleh Pemerintah. Partisipasi bisa bersifat individual atau kolektif, terorganisir atau spontan, mantap atau sporadik, secara damai atau dengan kekerasan, legal atau illegal, efektif atau tidak efektif.

Sementara pemilihan umum merupakan suatu contoh partisipasi politik yaitu kegiatan warga negara biasa dalam mempengaruhi kebijakan pemerintah. Pada hakekatnya pemilihan umum merupakan cara dan sarana yang tersedia bagi rakyat unutk menentukan wakil-wakilnya yang akan duduk dalam badan-badan perwakilan rakyat untuk menjalankan kedaulatan rakyat. Sangat bermaknanya pemilu bagi semua orang, maka pemilihan yang menjadi indikator demokratisnya suatu negara. Untuk menjaga kelangsungan penyelenggaraan pemerintahan yang dibentuk melalui mekanisme pemilihan umum maka keterlibatan masyarakat sangat dibutuhkan sebagai energi demokrasi itu sendiri. Pemilihan umum dengan makna demokratisnya adalah tempat berkompetisinya partai politik yang secara umum dapat menjadi tempat pembelajaran bagi elit dan komponen bangsa lainnya. Selain itu pemilihan umum juga terkait dengan peran serta masyarakat dalam memberikan dukungan kepada kandidat dan partai politik yang ada (Pamungkas, 2009, h.5)

Setidaknya ada tiga hal tujuan pemilihan umum (Phillips, W. Shively, 1987, h.147), yaitu: Pertama, sebagai mekanisme untuk menyeleksi para pemimpin pemerintahan dan alternatif kebijakan umum. Sesuai dengan prinsip demokrasi yang memandang rakyat yang berdaulat, tetapi pelaksanaannya dilakukan oleh wakil-wakilnya (demokrasi perwakilan). Oleh karena itu, pemilihan umum merupakan mekanisme penyeleksian dan pendelegasian atau penyerahan 
kedaulatan kepada orang atau partai yang dipercayai. Untuk menentukan alternatif kebijakan yang harus ditempuh oleh pemerintah biasanya yang menyangkut hal yang prinsipil beberapa negara menyelenggarakan pemilihan umum sebagai mekanisme penyeleksian kebijakan umum. Kedua, pemilihan umum juga dapat dikatakan sebagai mekanisme memindahkan konflik kepentingan dari masyarakat kepada badan-badan perwakilan rakyat melalui wakil-wakil rakyat yang terpilih atau melalui partai-partai yang memenangkan kursi sehingga integrasi masyarakat tetap terjamin. Hal ini didasarkan atas anggapan didalam masyarakat terdapat berbagai kepentingan yang tidak hanya berbeda, tetapi juga kadang-kadang saling bertentangan, dan dalam sistem demokrasi perbedaan atau pertentangan kepentingan tidak diselesaikan dengan kekerasan, melainkan melalui proses musyawarah (deliberation). Ketiga, pemilihan umum merupakan sarana memobilisasikan dan/atau menggalang dukungan rakyat terhadap negara dan pemerintahan dengan jalan ikut serta dalam proses politik. Hal yang ketiga ini tidak hanya berlaku di negara-negara berkembang, tetapi juga di negara-negara yang menganut demokrasi liberal (negara-negara industri maju), kendati sifatnya berbeda.

Demikian juga halnya dengan Pemilihan Kepala Daerah (Pilkada) merupakan instrumen yang sangat penting dalam penyelenggaraan Pemerintahan Daerah berdasarkan prinsip demokrasi di daerah, karena disinilah wujud bahwa rakyat sebagai pemegang kedaulatan menentukan kebijakan kenegaraan. Mengandung arti bahwa kekuasaan tertinggi untuk mengatur pemerintahan Negara ada pada rakyat. Melalui Pemilukada, rakyat dapat memilih siapa yang menjadi pemimpin dan wakilnya dalam proses penyaluran aspirasi, yang selanjutnya menentukan arah masa depan sebuah negara (Yusdianto, 2010, h.44)

Lebih jauh dapat dipahami bahwa Pemilihan Kepala Daerah merupakan rekuitmen politik penyeleksian rakyat terhadap tokoh-tokoh yang mencalonkan diri sebagai kepala daerah, baik Gubernur/Wakil Gubernur maupun Bupati/Wakil Bupati atau Walikota/Wakil Walikota. Dalam kehidupan politik di daerah, pemilihan kepala daerah merupakan salah satu kegiatan, yang memiliki nilai equivalen sama dengan pemilihan anggota DPRD. Equivalensi tersebut ditunjukkan dengan kedudukan sejajar antara kepala daerah dan DPRD. Hubungan kemitraan dijalankan dengan cara melaksanakan fungsi masing-masing sehingga terbentuk mekanisme check and balances. Oleh sebab itu, pemilihan kepala daerah sesungguhnya bagian dari sistem politik di daerah (Prihatmoko, 2005, h.203).

\section{METODE PENELITIAN}

Penelitian ini menggunakan metode kualitatif dengan pendekatan deskriptif analisis. Moleong (2009, h. 4) mendefinisikan metodelogi kualitatif sebagai prosedur penelitian yang menghasilkan data deskriptif berupa kata-kata tertulis atau lisan dari orang-orang dan perilaku yang dapat diamati. Penelitian ini melibatkan informan sebanyak 20 orang yang terdiri dari pengurus, dewan pengajar dan santri yang berada pada 2 dayah penelitian.

Teknik analisis data dilakukan dengan menggunakan teori Miles dan Huberman (2007, h.16) dimana analisis data terdiri dari tiga alur kegiatan yang terjadi secara bersama-sama yaitu pengumpulan data, reduksi data, penyajian data, penarikan kesimpulan/verifikasi yang dapat digambarkan dalam skema berikut: 


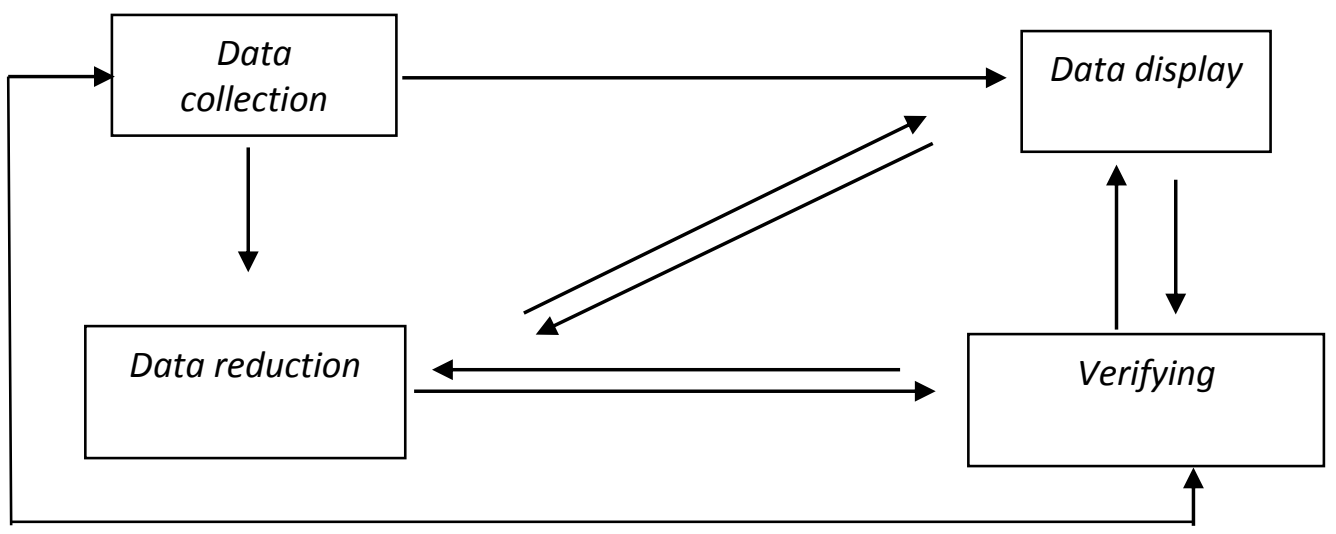

Bagan 3.1.

Komponen-Komponen Analisis Data Model Interaktif

(Miles dan Huberman, 2007, h.20)

\section{HASIL DAN PEMBAHASAN}

a. Hasil Penelitian

Penelitian ini dilakukan di 2 (dua) Dayah yang berada di kecamatan Meurebo Kabupaten Aceh Barat. Keberadaan kedua dayah yang di teliti dapat di lihat dalam tabel sebagai berikut:

Tabel 1. Lokasi Penelitian

\begin{tabular}{|c|c|c|c|}
\hline \multirow[b]{2}{*}{ No. } & \multirow[b]{2}{*}{ Identitas } & \multicolumn{2}{|c|}{ Nama Dayah } \\
\hline & & $\begin{array}{l}\text { Darul Hikmah } \\
\text { Islamiyah }\end{array}$ & Thariqussalam \\
\hline 1. & Pendirian & 27 Januari 1991 & 1970 \\
\hline 2. & Luas Area & $3000 \mathrm{~m}^{2}$ & $1200 \mathrm{~m}^{2}$ \\
\hline 3. & Sarpras & $\begin{array}{l}\text { Mushala, kantor dayah, } \\
\text { kampus, sekolah, pondok } \\
\text { (asrama), kantin dan } \\
\text { dapur umum. }\end{array}$ & $\begin{array}{l}\text { Mushala, kantor dayah, } \\
\text { kampus, sekolah, pondok } \\
\text { (asrama), kantin, dapur } \\
\text { umum, dan koperasi } \\
\text { dayah. }\end{array}$ \\
\hline 4. & Jumlah Ustaz & 25 orang & 10 orang \\
\hline 5. & Jumlah Ustazah & 13 orang & 4 orang \\
\hline 6. & Jumlah Santri & 195 orang & - \\
\hline 7. & Jumlah Santriawati & 133 orang & - \\
\hline 8. & Jumlah Santri Lepas & - & 100 orang \\
\hline 9. & Jumlah Santri Mondok & - & 40 orang \\
\hline
\end{tabular}

Sebagai mana diketahui, dayah merupakan institusi pendidikan agama Islam yang sangat berperan dalam mewujudkan tantanan masyarakat yang menunjung tinggi nilai-nilai keagamaan dan membangun intelektual santri-santrinya agar dapat mengikuti perkembangan dunia yang lebih dinamis yang sesuai dengan perkembangan ilmu pengetahuan, sosial, budaya dan politik. Berbicara politik dalam tatanan sosial masyarakat sekarang ini, keberadaan dayah seringkali dikaitkan dengan dinamika perpolitikan, khususnya pada saat pemilihan kepada daerah. Karena itu pula, keberadaan dayah kini telah menjadi ranah sosial politik dilihat dari penerimaan pimpinan pesantren terhadap kunjungan-kunjungan ke pesantren dalam rangka meminta dukungan atau sosialisasi pencalonan. Dengan demikian, perlu mengetahui bagaimana 
partisipasi santri dalam pesantren dalam pemilihan Kepala Daerah khususnya di Kabupaten Aceh Barat pada tahun 2017.

Keberadaan santri di 2 dayah yang diteliti ini "pada dasarnya tidak pernah menerima sosialisasi mengenai kepemiluan secara khusus namun lebih kepada masyarakat umum, seperti kepada tokoh masyarakat di Gampong yang dilakukan di kecamatan, kemudian di internal penyelenggara pemilu mulai dari PPK, PPS dan KPPS berkaitan dengan tahapan pelaksanaan Pilkada Aceh Barat" (Wawancara, 27 Maret 2017).

Berdasarkan hasil penelitian yang dilakukan "berkenaan dengan partisipasi santri, dari pihak penyelenggara pemilu tidak bisa memberikan klasifisikasi secara detail karena tidak pernah melakukan pendataan secara khusus untuk santri, karena daftar pemilih tetap dilihat dari pendataan pada basis desa, namun ada anggapan bahwa keikutsertaan atau keterlibatan santri dalam kampanye atau kegiatan safari politik adalah sesuatu yang positif' (Wawancara, 27 Maret 2017).

Pada sisi lain "peran pesantren dalam mendorong santri untuk ikut berpartispasi dalam pilkada Aceh Barat pada tahun 2017 sangat besar, karena calon Kepala Daerah juga meminta dukungan kepada Pimpinan Dayah, karena suara santri lebih pasti apabila mendukung calon tertentu, ini bukan menjadi rahasia umum lagi ketika kandidat kepala Daerah meminta dukungan kepada pimpinan Dayah agar pimpinan Dayah mendukung calon dan mendorong santri untuk memilih calon Kepala Daerah (Wawancara, 29 Maret 2017) sekaligus anggarapan umum dari para praktisi politik.

Praktisi politik lainnya menyebutkan bawah "partisipasi santri dalam memilih kalau memang sudah memilih itu sangat bagus, tetapi kalau berpartispasi untuk kampanye atau memobilisasi massa, menurut saya itu tidak bagus bagi santri (Wawancara, 31 Maret 2017).

Pegakuan lainnya dari praktisi politik menyebutkan bahwa mereka "tidak pernah melibat santri secara langsung dalam kampanye atau untuk memobilisasi pemilih lain agar memilih calon Kepala Daerah yang didukung oleh Partai, tapi kalau meminta dukungan kepada pimpinan pesantren tentu ada, demikian juga partai lainnya" (Wawancara, 29 Maret 2017). Demikian juga untuk melibatkan santri dalam kampanye partai untuk mendengar visi misi calon kandidat yang didukung partai tidak pernah, namun tentu saja melakukan kunjungan dan mengimbau saja agar santri diharapkan dapat memilih kandidat yang didukung partai pada hari pemilihan. Karena memang ini merupakan salah satu strategi partai untuk berkunjung ke (Wawancara, 31 Maret 2017).

Hasil wawancara dengan beberapa nara sumber di atas sepertinya juga diamini oleh pihak dayah-dayah lokasi penelitian bahwasanya "bagi santri yang telah memiliki hak pilih, sudah berpartisipasi memberikan dukungan dan memilih calon Kepala Daerah pada hari pemilihan Kepala Daerah Kabupaten Aceh Barat 2017 lalu yang mana santri yang sudah punya hak pilih dapat pulang ke Gampong masing-masing untuk memilih, karena di Dayah tidak disediakan TPS" (Wawancara, 2 April 2017). "dayah memberikan izin khusus bagi santri yang sudah memiliki hak pilih, agar bisa pulang ke Gampongnya untuk memilih calon Kepala Daerah (Wawancara, 10 April 2017).

Bahkan wujud dari partisipasi politik santri sebagai wujud warga negara yang baik adalah diantaranya ikut berpartisipasi aktif dalam Pemilihan Kepada Daerah Kabupaten Aceh Barat ada sebagian santri menjadi anggota KPPS, namun yang paling banyak adalah hanya memilih calon Kepala Daerah pada hari pemilihan saja" (Wawancara, 2 April 2017).

Namun demikian, pihak dayah juga mengakui bahwa "kalau untuk kampanye santri tidak pernah ikut serta, karena santri lebih mementingkan pengajian dari pada ikut kampanye calon Kepala Daerah" (Wawancara, 2 April 2017). "Santri Dayah tidak diperbolehkan untuk ikut dalam kampanye partai atau calon Kepala Daerah manapun, karena itu bukan kegiatan yang baik bagi santri, karena santri harus fokus dan berkonstrasi untuk belajar di Dayah" (Wawancara, 10 April 2017). "Pimpinan pesantren tidak pernah mendorong santri ikut serta 
dalam kampanye atau kegiatan seperti rapat-rapat dengan tim sukses calon Kepala Daerah. Pimpinan pesantren hanya memberikan saran kepada santri untuk memilih calon Kepala Daerah tertentu yang dianggap pimpinan Dayah beriman, bertaqwa dan baik dalam memimpin, tapi tidak pernah memaksakan kepada santri-santrinya (Wawancara, 2 April 2017).

Sebaliknya pada saat pelaksanaan pemilihan kepala daerah yang lalu, "santri yang usia di bawah 25 tahun tidak kami izinkan untuk ikut dalam kegiatan politik yang dibuat oleh partai, tim sukses calon Kepala Daerah karena santri harus fokus dengan pengajian Dayah. Kalau pun ada calon Kandidat yang datang ke Dayah sekalipun. Santri fokus ke pengajian bukan ke kampanye calon (Wawancara, 10 April 2017).

Namun demikian, pihak dayah juga mengakui bahwa pada dasarnya "tidak ada kegiatan yang berhubungan dengan pilkada secara khusus untuk mendorong santri agar aktif dalam pilkada, akan tetapi pimpinan dayah hanya memberikan izin kepada santri untuk pulang dan memilih sesuai dengan pilihan yang diinginkan" (Wawancara, 10 April 2017).

Hasil wawancara tersebut kemudian disingkronkan dengan data yang ditemukan dari para santri secara langsung yang rata-rata juga berpendapat sama seperti yang disampaikan oleh pihak pengelola dayah sebelumnya. "ikut berpartisipasi. Alasannya karena ada Calon Kepala Daerah yang memiliki visi dan misi untuk kemajuan daerah. Selain itu dengan berpartisipasi dalam memilih, akan dinilai oleh masyarakat sebagai warga negara yang baik, karena mau terlibat dalam Pemilukadasung" (Wawancara, 27 Maret 2017). Pendapat lainnya juga menyebutkan bahwa "ikut berpartisipasi. Alasannya karena ingin memilih salah satu calon Kepala Daerah di Kabupaten Aceh Barat dan juga sebagai kewajiban warga negara" (Wawancara 27 Maret 2017).

Lebih jauh mereka menyebutkan bahwa "sekarang ini partisipasi santri hanya sebatas memilih saja, untuk ikut kegiatan politik seperti kampanye, tidak dan belum pernah ikut (Wawancara, 27 Maret 2017). Pihak dayah hanya "memberikan motivasi kepada santri agar memilih Bupati yang bagus visi misinya" (Wawancara, 27 Maret 2017). "Tidak ada dorongan dari pimpinan dayah, cuma kami diizinkan pulang ketika hari pemilihan" (Wawancara, 27 Maret 2017).

\section{b. Pembahasan}

Seiring dengan demokratisasi di Indonesia dan kesempatan pendidikan yang tinggi oleh santri, banyak komunitas santri yang mulai tercerahkan dimana hal ini bisa kita lihat dari cara berpikir mereka yang mulai mengambil perannya dalam pelaksanaan demokrasi daerah khususnya pada saat diselenggaranya pemilihan umum kepala Daerah. Lebih jauh lagi bahwasanya konsep perilaku turut serta berpartisipasi politik merupakan sebuah hubungan timbal balik. Sedangkan memilih ialah suatu aktifitas yang merupakan proses menentukan sesuatu yang dianggap cocok dan sesuai dengan keinginan seseorang atau kelompok, baik yang bersifat eksklusif maupun yang inklusif. Memilih merupakan aktifitas menentukan keputusan secara langsung maupun tidak langsung. Perilaku memilih ialah keikutsertaan warga Negara dalam pemilihan umum merupakan serangkaian kegiatan membuat keputusan, yakni apakah memilih atau tidak memilih dalam pemilihan umum.

Demikian juga halnya dengan keberadaan dayah yang merupakan komunitas masyarakat yang hidup dengan berlandaskan nilai-nilai ajaran dan landasan agama Islam. Dayah memiliki peraturan yang mengikat para santri. Peraturan tersebut dibuat dengan tujuan untuk mendidik para santri agar disiplin dan mandiri. Sehingga setelah menempuh pendidikan di Dayah, santri mampu beradaptasi dengan kehidupan masyarakat. Peraturan Dayah seringkali mengikat santri sehingga tidak memiliki kebebasan sebagaimana remaja umumnya. Maka, posisi santri sebagai pemilih sangat berbeda dengan pemilih secara umum. Hal ini disebabkan kondisi santri yang harus tinggal di dalam lingkungan Dayah sehingga terikat dengan peraturan Dayah yang begitu ketat, belum lagi KIP Kabupaten Aceh Barat tidak melakukan sosialisasi mengenai Pemilukada 
kepada santri di Dayah-Dayah yang berada di Kabupaten Aceh Barat secara khusus, namun sosialisasi difokuskan pada masyarakat dan tokoh masyarakat yang berada di desa-desa ditempat terselenggaranya Pilkada.

Namun demikian, santri tetap memiliki antusiasisme yang sama sebagaimana pemilih pemula selain santri untuk berpartisipasi dalam pemilihan kepala daerah di Kabupaten Aceh Barat pada tahun 2017.

Pada dasarnya, baik Dayah Darul Hikmah Islamiyah maupun dayah Thariqussalam memberikan kebebasan kepada santrinya untuk berpartisipasi dalam pemilihan kepala Daerah Kabupaten Aceh Barat dimana sebagian santri di dua dayah tersebut dikategorikan sebagai pemilih pemula. Partisipasi yang dilakukan oleh santri sebagai pemilih pemula adalah berupa menggunakan hak pilih dalam pemilihan calon Kepala Daerah dalam pemilihan Kepala Daerah di Kabupaten Aceh Barat namun tidak terlibat dalam kegiatan politik praktis lainnya.

Selama ini masyarakat bahkan elit politik masih beranggapan keterlibatan santri dalam memilih calon Kepala Daerah, tidak lepas dari adanya kegiatan yang masif dilakukan oleh pimpinan Dayah memobilisasi santri untuk memilih dan memberikan dukungan yang sesuai dengan pilihan pimpinan Dayah, karena partisipasi santri yang terbatas pada memilih calon Kepala Daerah tanpa disertai dengan partisipasi santri dalam kegiatan kampanye atau memobilisasi pemilih lain untuk memilih satu calon Kepala Daerah.

Selain itu adanya stigma masyarakat bahwa di dayah-dayah yang tersebar di Kabupaten Aceh tidak lepas dari pengamatan elit politik partai yang bersedia diajak untuk mendukung salah satu calon Kandidat dalam Pilkada, dengan harapan nantinya pemimpin dayah pun dapat menggiring santri sebagai pemilih pemula untuk memberikan suara politiknya kepada salah satu calon Kepala Daerah. Hal tersebut karena santri adakalanya merupakan pemilih yang sifatnya patron klien atau lebih dikenal dengan sebutan 'takzim ke guru'.

Berdasarkan hasil penelitian yang dilakukan menunjukkan bahwa santri diberikan izin untuk pulang ke Gampongnya untuk dapat memilih calon Kepala Daerah pada pilkada Kabupaten Aceh Barat. Hanya saja, kedua dayah tersebut melarang santri-santrinya untuk ikut berpartisipasi dalam kegiatan politik yang diselenggarakan oleh partai maupun calon Kepala Daerah, dengan alasan santri memiliki kewajiban untuk fokus belajar di Dayah.

Namun demikian, partisipasi politik dalam Pilkada Kabupaten Aceh Barat dalam lingkungan salah satu dayah yang di teliti khususnya dilakukan secara pribadi oleh pimpinan dayah tanpa membawa nama dayah, selanjutnya santri pada dayah pun dibatasi partisipasi politiknya. Artinya santri dalam politik hanya dibatasi pada kegiatan memilih calon Kepala Daerah sesuai dengan keinginan santri atau dalam kata lain partisipasi politik santri adalah partisipasi politik pasif dikarenakan santri tidak diperbolehkan aktif ikut serta dalam kegiatan-kegiatan kampanye dan memobilisasi massa untuk memilih calon tertentu sesuai dengan pilihan pribadi pimpinan dayah yang bersimpatik pada salah satu calon yang pernah berkunjung ke dayah, bahkan sampai kepada taraf pemberian restu serta dukungan kepada Calon Kepala Daerah tersebut.

Kunjugan para kontestan pemilu tentu saja punya alasan kuat yang mana calon tersebut beranggapan bahwa pimpinan dayah memiliki massa santri untuk dimobilisasi dalam pemilihan Kepala Daerah Kabupaten Aceh Barat. Namun demikian keputusan untuk mendukung atau tidak dari pimpinan Dayah, maka dalam hal ini pun pimpinan dayah hanya memberikan dukungan lebih bersifat pribadi bukan mengatasnamakan lembaga Dayah dengan tidak melibatkan ataupun mengajak santri untuk memilih calon kepala Daerah tertentu sesuai dengan keinginan pribadi pimpinan Dayah.

Berdarkan berbagai paparan yang disebutkan di atas terlihat bahwa partisipasi politik santri pada dua dayah yang diteliti mengarah kepada jenis partisipasi pasif sebagaimana yang digambarkan oleh Rahman H.I. (2007; 288) bahwa partisipasi politik dapat di bagi kepada tiga jenis yaitu:

1. Partisipasi aktif, yaitu partisipasi yang berorientasi pada proses input dan output. 
2. Partisipasi pasif, yaitu partisipasi yang berorientasi hanya pada output, dalam arti hanya menaati peraturan pemerintah, menerima dan melaksanakan saja setiap keputusan pemerintah.

3. Golongan putih (golput) atau kelompok apatis, karena menganggap sistem politik yang ada menyimpang dari yang dicita-citakan.

Sedangkan jika merunut kepada pendapat Milbrath dan Goel yang di kutip oleh Cholisin (2007:152), partisipasi politik yang dipraktikkan oleh santri pada dua pesantren yang di teliti mengarah kepada jenis partisipasi politik spector, dimana Milbrath dan Goel membedakan partisipasi politik menjadi beberapa jenis, yaitu:

1. Partisipasi politik apatis, orang yang tidak berpartisipasi dan menarik diri dari proses politik.

2. Partisipasi politik spector, orang yang setidak-tidaknya pernah ikut memilih dalam pemilihan umum.

3. Partisipasi politik gladiator, mereka yang secara aktif terlibat dalam proses politik, yakni komunikator, spesialis mengadakan kontak tatap muka, aktivis partai dan pekerja kampanye dan aktivis masyarakat.

4. Partisipasi politik pengritik, orang-orang yang berpartisipasi dalam bentuk yang tidak konvensional.

Namun demikian, Gabriel A. Almond mengungkapkan sebagai mana yang di kutip oleh Mas'oed dan MacAndrews dalam Damsar $(2010,186)$, bahwa Almond membedakan partisipasi atas dua bentuk, yaitu :

1. Partisipasi Politik konvensional, yaitu suatu bentuk partisipasi politik yang "normal" dalam demokrasi modern.

2. Partisipasi politik nonkonvensional, yaitu suatu bentuk partisipasi politik yang tidak lazim dilakukan dalam kondisi normal, bahkan dapat berupa kegiatan illegal, penuh kekerasan dan revolusioner.

TABEL 2

BENTUK-BENTUK PARTISIPASI POLITIK

\begin{tabular}{|c|c|}
\hline Konvensional & Non Konvensional \\
\hline Pemberian suara (voting) & Pengajuan Petisi \\
\hline$\sigma^{-}$Diskusi Politik & Berdemonstrasi \\
\hline $\begin{array}{l}\text { Membentuk dan bergabung dalam } \\
\text { kelompok kepentingan }\end{array}$ & Konfrontasi \\
\hline \multirow[t]{3}{*}{$\begin{array}{l}\text { Komunikasi individual dengan } \\
\text { pejabat politik dan administratif }\end{array}$} & Mogok \\
\hline & $\begin{array}{l}\text { Tindak kekerasan politik terhadap } \\
\text { hartabenda(perusakan,pengeboman,pembak } \\
\text { aran) }\end{array}$ \\
\hline & $\begin{array}{l}\text { Tindakan kekerasan politik terhadp manusia } \\
\text { (penculikkan,pembunuhan) perang gerilya } \\
\text { dan revolusi. }\end{array}$ \\
\hline
\end{tabular}

Sementara bila di lihat berdasarkan hirarki partisipasi politik, maka partisipasi politik yang diperankan oleh santri pada dua dayah yang diteliti mengarah kepada bentuk partisipasi hirarki level 2 di atas hirarki terendah yaitu apatis. Sebagaimana yang disebutkan oleh Rush dan Althoff dalam Damsar $(2010,185)$ bahwa "hirarki tertinggi dari partisipasi politik adalah menduduki jabatan politik atau administrative. Sedangkan hierarki yang terendah dari suatu partisipasi politik adalah orang yang apati secara total, yaitu orang yang tidak melakukan aktivitas politik apapun secara total. Semakin tinggi hirarki partisipasi politik maka semakin 
kecil kuantitas dari keterlibatan orang-orang, seperti yang diperlihatkan oleh Gambar Hierarki Partisipasi Politik, dimana garis vertikal segitiga menunjukkan hierarki, sedangkan garis horizontalnya menunjukkan kuantitas dari keterlibatan orang-orang.

\section{Gambar I}

\section{Hierarki Partisipasi Politik}

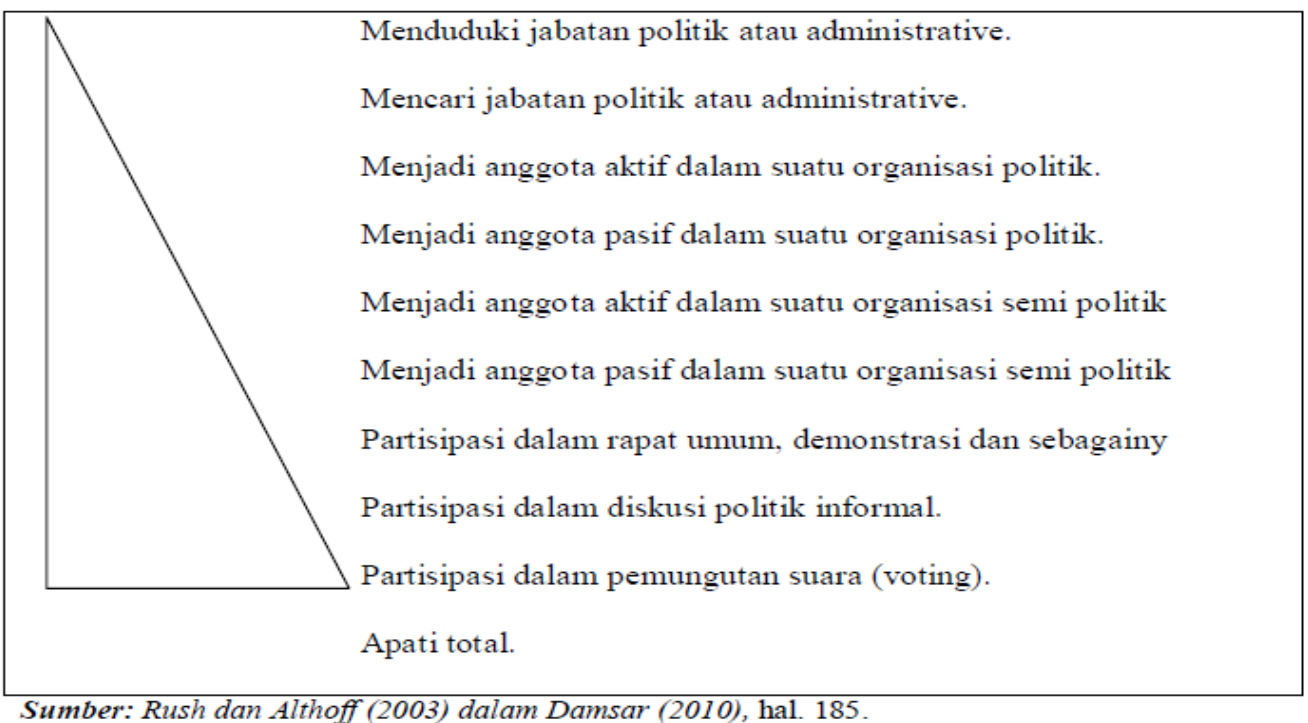

Berdarkan gambar tersebut di atas, terlihat bahwa praktik partisipasi yang dijalankan oleh para santri dalam dua dayah yang di teliti mengarah kepada hirarki partisipasi yang dasar sekali dimana partisipasi ini merupakan di atas dari sikap apati total yang tidak mau tau dengan situasi pemilihan atau pemungutan suara bahkan lebih jauh hingga kepada tidak ikut dalam pencoblosan. Namun demikian, keberadaan santri yang hanya mempergunakan hak pilihnya pada hari pelaksanaan pencoblosan menunjukkan bahwa dayah ikut berkontribusi dalam memberikan pemahaman kepada para santri untuk mempergunakan hak pilihnya sebagai warga negara yang baik.

\section{SIMPULAN}

Berdasarkan hasil penelitian yang telah dilakukan, maka dapat disimpulkan bahwa partisipasi politik santri dalam pemilihan Kepala Daerah Kabupaten Aceh Barat adalah partisipasi pasif dengan bentuk partisipasi konvensional dan berada pada hirarki terendah atau satu level diatas sikap apatis (golput), karena santri hanya menggunakan hak politiknya yang terbatas pada memilih salah satu calon Kepala Daerah dalam pemilihan Kepala Daerah Kabupaten Aceh Barat pada tahun 2017. Hal ini dikarenakan baik pimpinan Dayah Darul Hikmah Islamiyah maupun Dayah Thariqussalam tidak memberikan izin kepada santri untuk ikut berpartisipasi dalam kegiatan politik secara aktif, namun hanya memberikan izin untuk pulang ke kampung masing-masing pada saat hari pemilihan saja atau pada hari pencoblosan.

\section{REFERENSI}

A. Rahman.H.I. 2007. Sistem Politik Indonesia. Yogyakarta: Graha Ilmu. Arifin, Muzayyi. 2007. Kapita Selekta Pendidikan Islam. Jakarta: PT Bumi Aksara Bappeda. 2014. Aceh Barat dalam Angka tahun 2014. Meulaboh.

Budiarjo, Miriam. 2007. Dasar-Dasar Ilmu Politik. Jakarta: PT. Gramedia Pustaka Utama. 
Cholisin, dkk. 2007. Dasar-Dasar Ilmu Politik. Yogyakarta: UNY Press.

Damsar. (2010). Pengantar Sosiologi Politik. Jakarta: Kencana Prenada Media Group.

Huntington, Samuel dan Nelson, Joan. 1994. Partisipasi Politik di Negara Berkembang. Jakarta: Rineka Cipta.

Miles dan Huberman. 2007. Analisis Data Kualitatif. Jakarta: Universitas Indonesia Press.

Moleong, Lexy. 2009. Metodelogi Penelitian Kualitatif. Bandung: Remaja Rosdakarya.

Pahmi SY, 2010, Politik Pencitraan, Jakarta; Gaung Persada Press.

Pamungkas, Sigit. 2009. Perihal Pemilu. Yokyakarta: UGM Press.

Phillips, W. Shively, 1987, Power and Choice: An Introduction to Political Science, New York: Random House.

Prihatmoko, Joko. 2005. Pemilihan Kepala Daerah Langsung, (Filosofi, Sistem dan Problema Penerapan di Indonesia). Yogyakarta: Pustaka Pelajar.

Shofiya, Ana. 2014. Orientasi Politik Santri Sebagai Pemilih Pemula Dalam Pemilihan Gubernur Jawa Timur Tahun 2013 (Studi Pada Santri Di Pondok Pesantren Roudlotun Nasyi'in Desa Beratkulon Kecamatan Kemlagi Kabupaten Mojokerto). Jurnal Kajian Moral dan Kewarga- negaraan Nomor 2 Volume 2 Tahun 2014, hal 611-624.

Tafsir, Ahmad. 2012. Ilmu Pendidikan Islami. Bandung: PT Remaja Rosdakarya.

Yusdianto. 2010. Identifikasi Potensi Pelanggaran Pemilihan Kepala Daerah (Pemilukada) dan Mekanisme PenyelesaiiannyaI. Jurnal Konstitusi Vol II nomor 2, November 2010. 